\title{
INTEGRATING BUSINESS START-UP INDICATORS IN THE FLEXICURITY CONCEPT TO COVER THE ALTERNATIVE FORMS OF EMPLOYMENT
}

\author{
Agnese Vaivade ${ }^{1}$, Edgars Brekis $^{2}$, Erika Sumilo ${ }^{3}$ \\ Faculty of Economics and Management, University of Latvia, Aspazija blvrd. 5, Riga, Latvia \\ E-mails: ${ }^{1}$ agnese.vaivade@lu.lv (corresponding author); ${ }^{2} d r . e . b @ i c l o u d . c o m ;{ }^{3}$ erika.sumilo@lu.lv
}

\begin{abstract}
The flexicurity concept created in the Netherlands and Denmark in the early 1990s has become the main stepping-stone in improving the performance of labour markets across the European Union Member States. The European Commission has therefore taken a leading role on broader flexicurity concept development and creation of the data analysis methodology. However, the analysis proposed by the European Commission Joint Research Centre on flexicurity indicators in 2010 only partly includes business start-ups as a flexible form of employment. This research starts the discussion on whether additional indicators should be integrated in the flexicurity analysis, because of the rising need for employment security through entrepreneurial activity.
\end{abstract}

Keywords: active labour market policy, cluster analysis, flexicurity, flexibility, self-employment, start-up.

JEL Classification: D86; J08; L14.

\section{Introduction}

Since the global financial crisis in 2007, the European Commission (EC) has taken a leading role in helping the European Union (EU) Member States (MS) to increase their competitiveness by improving their labour, product, capital and financial markets. The relatively recent innovation in the analysis of labour markets is the flexicurity concept; the objective of which is to balance labour market flexibility and employment security. The history of flexicurity starts already in the early 1990s in Denmark and the Netherlands, but in 2007, the EC made a common approach for the MS by defining the four principles, or pillars, and the background indicators relevant for flexicurity analysis. The necessity for further actions was strong, and therefore the studies continued; and in 2010, the EC Joint Research Centre came up with four composite indicators (for each of the pillars), where much more data were suggested than the first time in 2007, or as have been used by other academic researchers such as in Eamets et al. (2015). However, it seems that some parts are still missing. For example, one of the Active Labour Market Policies' instruments already incorporated in the flexicurity analysis, is spending to help unemployed people start their own businesses, particularly called the "LMP expenditure: cat.7, Startup incentives". The flexicurity concept, however, does not include data on the actual start-up activity or programme efficiency. Including indicators such as enterprise birth rates, employment in newlyborn enterprises, and surviving rates, could improve the estimate of the labour market flexicurity in the MS. Hierarchical cluster analysis is used to group countries under a traditional flexicurity framework, by business start-up indicators, and by combination of both.

The aim of the study is to advocate additional indicators to be integrated into the flexicurity concept, in order to improve the overall analysis and understanding of labour market flexicurity across the MS. The findings suggest that by introducing new business start-up indicators in the flexicurity analysis, Scandinavian countries (Denmark, Finland, and Sweden) still form the benchmarking cluster for Europe, while the picture of grouping other countries becomes mixed: particularly, a number of Eastern European countries are able to "catch-up" with Central Europe, because of good performing business indicators.

The paper is organized as follows - a literature review describes the four pillars of the flexicurity concept, as well as envisaging self-employment and business start-ups as alternative forms of employment. It is followed by the description of existing practice on selection of indicators for flexicurity analysis, and suggesting business start-up indicators that could be integrated. In the final section, the performance of EU MS is analysed under the flexicurity concept, business statistics and the combined data set of the two. The main findings of the paper are gathered in the conclusions.

(C) 2016 The Authors. Published by VGTU Press. This is an open-access article distributed under the terms of the Creative Commons Attribution License (CC-BY 4.0), which permits unrestricted use, distribution, and reproduction in any medium, provided the original author and source are credited. 


\section{Literature review on the flexicurity concept and business start-ups as an alternative form of employment}

\subsection{Flexicurity in the Netherlands}

The flexicurity concept was first developed in the Netherlands in the 1980s, when changes in the economy were towards a more flexible labour market, but decreasing social security and benefits. This was mainly because the generous and universal social security system that was built after the Second World War could no longer withstand the first and the second oil crisis in the 1970s. Therefore, at that time, government first started a reduction in the earning replacement ratios, and increased the conditions for entitlement to unemployment or disability benefits. Later, with the Wassenaar Agreement (1982), the moderation of wage increase for the industry (the national "wage stop") in order to increase the competitiveness of the industry was compensated by a reduction in the working hours, in the interest of trade unions. Since 1994, the government started work on the reduction of taxes, and the contributions levied on low wages in order to stimulate lowincome employment, and increase the stimulus for flexible labour contracts (Van Oorschoot, Engelfriet 2000). To correct the increasing social risks when flexibility is promoted and social security limited, professor Hans Adriaansens from the Dutch Scientific Council of Government Policy introduced, in 1995, the approach of employment security, instead of job security. The idea of improved employment opportunities became more important, which today is reflected in the lifelong learning (LLL) and active labour market policy (ALMP).

\subsection{Flexicurity in Denmark}

The development of the flexicurity concept as it is seen nowadays in Denmark intensified around the same time as in the Netherlands, and it resulted in a well-defined model, today called the Danish "Golden Triangle". The initial phase started with negotiations between the government, employers and trade unions in the early 1990s. It resulted in important labour market reforms, specifically in the implementation of the ALMP. The aim of ALMP was to break the rising unemployment rate, which reached its maximum at $12.4 \%$ in 1993 . The "Golden Triangle" is a combination of three elements: (a) numerical flexibility, estimated by employment protection legislation; (b) social security characterised by generous unemployment benefits; and (c) ALMP, especially the support for job search and training (Origo, Pagani 2009). But the model has a long background history. The low employment protection legislation that stimulates workers' mobility was first introduced in 1899 with the so-called "September Compromise" between the social partners. The unemployment benefit system was revised in 1969, but the first activation measures started already in 1979 (Madsen 2005).

\subsection{The flexicurity concept, as defined by the European Commission}

In the European context, labour market flexicurity was first time introduced through Integrated Guideline No. 21 in the revised Lisbon Strategy in 2005: "Promote flexibility combined with employment security and reduce labour market segmentation, having due regard to the role of the social partners" (European Council 2005). But in 2007, the EC introduced four flexicurity pillars: (a) flexible and reliable contractual arrangement through modern labour laws, collective agreements and work organisation; (b) comprehensive lifelong learning strategies; (c) effective active labour market policies; and (d) modern social security system that provides adequate income support and encourages employment, and facilitates labour market mobility. According to Muffels and Wilthagen (2013) in labour markets, there is external numerical (hiring and firing), internal numerical (working-time), internal functional (adaption of the internal work organization to the product demand), and wage flexibility; and then there is job, employment, income, and combined (work-life balance) security. The four pillars of flexicurity include all the various forms of flexibility and security; therefore, they have become the basis of flexicurity analysis in the EU both in qualitative and quantitative terms.

\subsection{Relation between flexibility, unemployment, and self-employment (incl. start-ups)}

The most popular flexibility estimate is the employment protection legislation (EPL) index introduced by the Organisation for Economic Cooperation and Development (OECD), which show the strictness of regulation on dismissals of regular and/or temporary employees, individually and/or collectively. However, not only is traditional employment affected by the EPL, but so is selfemployment and start-ups. Depending on the level of EPL the relative risk of being self-employed changes. If the EPL is very high, self-employment 
or start-ups become relatively riskier than to be a regular employee. But the relationship between EPL and self-employment are found to be nonlinear by Milan et al. (2010), and having an inverted U-shaped pattern. They suggest that "additional increases in the degree of protection would lower the risk of exiting self-employment", when the EPL is below the U-shaped breaking point, but "once a determined level of protection is reached (the turning point), a stricter EPL imposes hiring and firing costs that the self-employed can often least afford". Therefore, the longest surviving rates of self-employees and start-ups will be in the country with a moderate level of EPL. It has also been found that higher tax and social contributions, such as unemployment benefits, decrease survival rates because the opportunity cost of self-employment in both cases increases (Milan et al. 2010). As suggested by Roman et al. (2013): "public expenditure designed to move the unemployed back to employment might be detrimental for employment rights and the social protection of workers by favouring the development of atypical forms of employment that are outside the scope of labour laws".

There are two opposite theories about the relations between unemployment and self-employment:

- The "unemployment push" hypothesis high unemployment may reduce the opportunity to gain traditional employment and thus positively affect self-employment, also known as the "refugee" effect, which suggests that increasing unemployment leads to increasing start-up activity because of the decrease in the opportunity costs of starting a firm.

- The "unemployment pull" hypothesis unemployed people tend to have lower human capital and entrepreneurial talent to start and sustain a new firm. Also known as the "entrepreneurial" effect, which suggests that high unemployment may be associated with a low degree of selfemployment (Thurik et al. 2008).

Higher start-up creation has been found during recession in Germany, by Fritsch et al. 2013), which implies counter-cyclical business formation, and the "unemployment push" effect to work in times of high total unemployment. The findings by Thurik et al. (2008) suggest that "unemployment push"/"refugee" effect is relatively small, therefore the policy should be focused on encouraging overall entrepreneurship that would lead to decreasing unemployment when unemployed individuals be- come employed on their own or by other start-ups. This is in line with the "Schumpeter effect" when new firms and start-ups reduce the level of unemployment, but not necessary when unemployed people move into self-employment (Halicioglu, Yolac 2015).

However, there is bidirectional causality between unemployment variation and entrepreneurship found by Faria et al. (2010), specifically in countries that have the most flexible labour markets. Furthermore, the relation between unemployment and start-ups are also found to be dynamic, nonlinear, and cyclical (Congregado et al. 2010b; Cichocki 2012; Faria et al. 2010; Fritsch et al. 2013). Cichocki (2012) shows, in the case of Poland, that the relation between unemployment and self-employment within one nation can be countercyclical for one group, while cyclical for another.

In either way, as long as the overall employment share by start-ups is low, the contribution to reduce unemployment is limited. At the same time, too high self-employment could point to the limits of economies of scale, or the lack of innovation, and research and development (Audretsch et al. 2005).

\subsection{Start-up incentives and their effectiveness}

The ALMP pillar has the purpose of turning unemployed persons back to employment, or prevent employed persons from involuntary job loss. By definition of the EC, ALMP covers different activation measures: training, employment incentives, supported employment and rehabilitation, direct job creation, and start-up incentives. Based on data from Eurostat, since 2005, approximately 60 million euros are spent each year in the EU on ALMP measures, with the highest peak in 2010. That corresponds to about an average of $0.5 \%$ of the EU MS gross domestic product (GDP). Denmark has been spending more than $1.3 \%$ of GDP since 2010 on ALMP, and more than $1.6 \%$ of GDP on passive labour market policies (PLMP). The average PLMP expenditures in the EU MS have been about $1 \%$ of GDP.

There are many studies done with the aim to estimate the efficiency of ALMP, and particularly the efficiency of the financing for start-up and selfemployment incentives within the ALMP framework (Baumgartner, Caliendo 2008; Caliendo, Kunn 2011; Congregado et al. 2010a; Millan et al. 2010; Roman et al. 2013). Part of these studies proves the necessity of the ALMP programmes (Card et al. 2010), while other researchers suggest that ALMP programmes are ineffective (Hujer et al. 2009). Findings by Card et al. (2010) show 
that, firstly, the results from ALMP programmes in the short term are heterogeneous, slightly more likely to be significantly positive than significantly negative, but in the medium and long terms, the likelihood of positive outcomes increases; second$1 y$, the results differ across country groups, for example, better results in the short term are found in Australia, New Zealand, Canada, US, and UK than in Germany, Austria and Switzerland, but it is mainly explained by the heterogeneity in the types of programmes in these countries.

Baumgartner and Caliendo (2008) estimated the effectiveness of two start-up programmes (bridging allowance and start-up subsidy) for unemployed ALMP participants in Germany and found that both programmes were effective in preventing unemployment and gave individuals much higher chances of remaining employed. The two programmes also had positive income effects - the income of people becoming self-employed was higher than for those who stayed in unemployment and continued to receive unemployment benefits and/or other governmental support.

Results of income effect also differ from study to study, as well as the results of start-up incentives on different sub-groups of participants. As found by Roman et al. (2013) higher own-account work chances in the presence of start-up incentives were true for unemployed individuals in time of high total unemployment or those not receiving unemployment benefits. This has been explained by characterizing these people as "natural candidates", who are going to accept any available form of employment, even the form of self-employment. The study by Congregado et al. (2010a) also confirms the view of self-employment "as a last resort for low-skilled, unemployed individuals, who might return to unemployment when incentives disappear or enter paid employment when job offers are available". Positive effect of start-up subsidies on self-employment is also confirmed with results by Millan et al. (2010): "When introducing variables at the macro level, our results show that the expenditure on start-up subsidies decreases the risk of exiting self-employment precisely for the group of individuals entering self-employment from unemployment - i.e., the target group for these incentives. In addition, we also find that expenditure on employment incentives reduces the hazard for all self-employed individuals, whatever their starting status." All these findings lead to argue that start-up incentives should focus more on high-growth company creation (Roman et al. 2013), while they have a strong effect on reducing unemployment in periods of economic and job cri- sis. Indicators used for evaluating start-up and selfemployment incentives are most often survival rate, number of jobs created by the new business, and change in level of income of participants (Baumgartner, Caliendo 2008; Millan et al. 2010; Roman et al. 2013).

\section{Proposal on broader perspective of flexibility indicators in the flexicurity concept}

The research on flexicurity has continued, especially in the area of measurements and estimation methodologies. At first, when defining the flexicurity at the European level, the EC proposed to have several indicators under each of the four pillars as well as to look at overall labour market outcomes. In 2010, the EC Joint Research Centre came up with a new methodology - the four composite indicators, this time the number of variables used in each of the pillars substantially increased, but the labour market outcome indicators were left out. Most often variables used for flexicurity analysis among researchers are EPL for regular and/or temporary contracts with individual and/or collective dismissals (Andersen 2012; Boeri et al. 2012; Eamets et al. 2015; EC 2010; Eurofound 2007; Maselli 2010; Tangian 2007; Vaivade, Brekis 2015), unemployment rate (Andersen 2012; Dal Bianco et al. 2015), long-term unemployment rate (Andersen 2012; Eamets et al. 2015; Eurofound 2007; Maselli 2010; Vaivade, Brekis 2015), the share of atypical employment as temporary, parttime, and self-employment (Eamets et al. 2015; EC 2010; Eurofound 2007; Vaivade, Brekis 2015), participation rate lifelong learning (Eamets et al. 2015; EC 2010; Eurofound 2007; Maselli 2010; Vaivade, Brekis 2015), expenditure on ALMP in percentage of GDP and/or per unemployed capita (Andersen 2012; Dal Bianco et al. 2015; Boeri et al. 2012; Eamets et al. 2015; EC 2010; Maselli 2010; Vaivade, Brekis 2015), expenditure on PLMP in percentage of GDP and/or per unemployed capita (Dal Bianco et al. 2015; Boeri et al. 2012; Eamets et al. 2015; EC 2010; Vaivade, Brekis 2015), net replacement ratios (Andersen 2012; EC 2010; Maselli 2010; Vaivade, Brekis 2015), unemployment trap (EC 2010), inactivity trap (EC 2010), risk at poverty (Eamets et al. 2015, Eurofound 2007; Maselli 2010; Vaivade, Brekis 2015), and others.

While there is no incontrovertible evidence of a relation between unemployment and selfemployment, or effectiveness of start-up incentives, it is clear that general entrepreneurial policy increases employment levels through several chan- 
nels. "EPL and start-up incentives are expected to be some of the most important labour market institutions to influence the occupational choice of unemployed individuals. [...] It is also since start-up programmes are the objectives of ALMP, when start-ups became part of employment policy instead of entrepreneurship policy" (Roman et al. 2013). Therefore, based on findings in the literature review about the interconnections among flexibility, unemployment, self-employment and startups, additional data could be used to integrate the start-ups as an alternative form of employment into the flexicurity analysis. None of these indicators focuses particularly on unemployed persons moving into self-employment or having start-up, rather it has a general perspective of entrepreneurial activity:

1. Birth rate: number of enterprise births in the reference period $(t)$ divided by the number of enterprises active in $t-$ Businesses economy except activities of holding companies (Eurostat). The number of start-ups is appraisement on both the scope of start-up incentives and favour of entrepreneurial environment. Birth rates can also capture the effect of relative risk for starting entrepreneurial activity in comparison to being in traditional employment. It is one of the indicators used to estimate the effectiveness of start-up incentives.

2. Employment share of enterprise births: number of persons employed in the reference period ( $t$ ) among enterprises newly born in $t$ divided by the number of persons employed in $t$ among the stock of enterprises active in $\mathrm{t}$ - Businesses economy except activities of holding companies (Eurostat). The indicator has the same characteristics as share of temporary, parttime workers, and share of selfemployment in total employment. It shows the share of employees involved in one of the non-traditional forms of job (a startup).

3. Survival rate 3 : number of enterprises in the reference period ( $t$ ) newly born in $t-3$ having survived to $t$ divided by the number of enterprises births in $\mathrm{t}-1$ - Businesses economy except activities of holding companies (Eurostat). Analysing survival rates is one of the approaches on estimating the effectiveness of start-up incentives, and the overall entrepreneurial environment. It could be the case when start-up is active during the period of activation measure on- ly. If survival rates over medium term are high enough, the start-up incentives have been effective and the business environment supports sustainability and growth. Only through longer period of time startups can employ higher number of people and have an effect on reducing unemployment ("Schumpeter effect").

4. Starting a Business indicator from Doing Business index by the Word Bank Group. This is a descriptive statistics of legislative framework for business creation and has similar meaning to EPL, which characterise the legal environment of traditional employment. Starting a Business indicator captures the costs (both time and money) of establishing the company.

\section{The analysis of flexicurity and suggested business start-up indicators in European Union member states}

The following variables are selected as the common indicators to describe the flexicurity concept in this paper: EPL (strictness of employment protection - individual and collective dismissals on regular contracts) and net replacement ratios (67\% of average wage for single person with no children and with initial stage of unemployment) by OECD, and share of part-time employment, share of selfemployment, long-term unemployment rate, labour market expenditure on ALMP as percentage of GDP, labour market expenditure on PLMP as percentage of GDP, at risk of poverty rate (cut-off point: $60 \%$ of median equalised income after social transfers), GINI index, and participation rate in LLL (persons aged 25 to 64, who stated that they received education or training in the four weeks preceding the survey) by Eurostat. All four proposed business start-up indicators are incorporated in the broader analysis of flexicurity. The analysis is based on data from year 2012 to have as complete sample as possible, but still several countries are omitted because of missing data. These are Bulgaria, Croatia, Cyprus, Greece, Lithuania, Malta, Romania, and the UK. The UK has not reported on the expenditures of active and passive labour market policies, which is also the case for Greece. All other countries are missing data on EPL.

Researchers use a wide set of methodologies and approaches to group countries by their similarities in implementation of flexicurity. Eamets et al. (2015) uses Agglomerative Hierarchical Clustering (AHC) and concludes that there are three plus one clusters, where the fourth consists of countries 
changing their location depending on the year chosen; Eurofound (2007) defines six clusters, EC (2012) defines five, but Origo and Pagani (2009) and EC (2010) found four main groups when using the principal component analysis. In this paper the AHC by Average Linkage and Ward's method is chosen for cluster analysis on standardized data, and the data analysis software " $\mathrm{R}$ " is used.

When clustering countries by flexicurity indicators only, following clusters have formed (see Figs 1 and 2):

1. Scandinavian cluster (Denmark, Finland, and Sweden).

2. Southern European cluster (Italy, Spain, and Portugal) together with Latvia.

3. Central European cluster (Germany, France, and Austria).

4. Eastern European cluster (Hungary, Slovakia, Poland, and Estonia).

Cluster analysis by flexicurity indicators

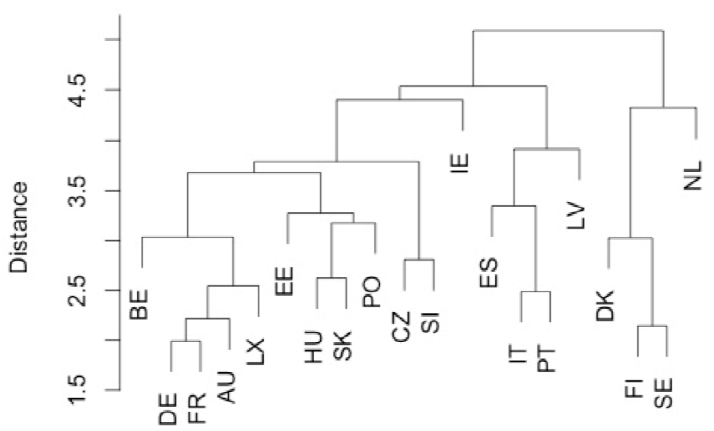

Country code

Fig. 1. Cluster analysis of flexicurity indicators by Average Linkage method (Source: author's calculations)

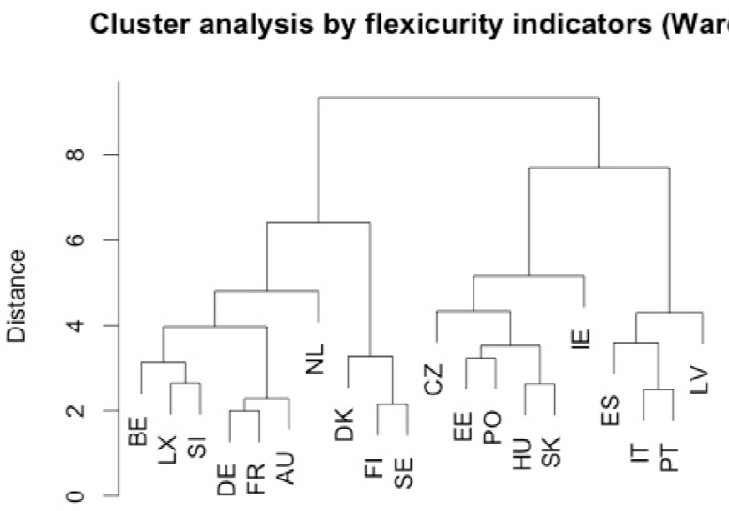

Country code

Fig. 2. Cluster analysis of flexicurity indicators by Ward's method (Source: author's calculations)
The Netherlands and Ireland are outliers and do not belong to any cluster whatever method is used, and all the other countries (Belgium, Luxembourg, the Czech Republic, and Slovenia) change their location among clusters (see Figs 1 and 2).

It is important to look at the grouping of countries, when only business start-up statistics is used, before incorporating the indicators into flexicurity analysis. The main finding is that clusters do not have a geographical dimension as before.

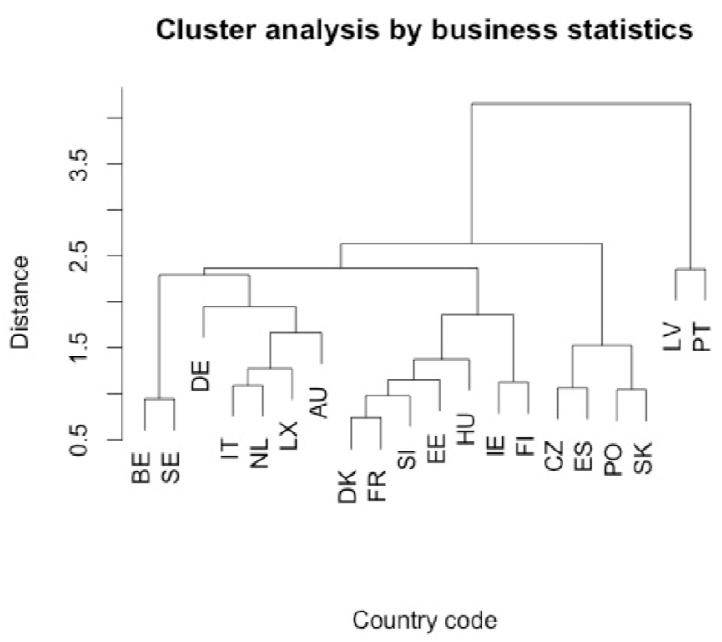

Fig. 3. Cluster analysis of business statistics by Average Linkage method (Source: author's calculations)

\section{Cluster analysis by business statistics (Ward)}

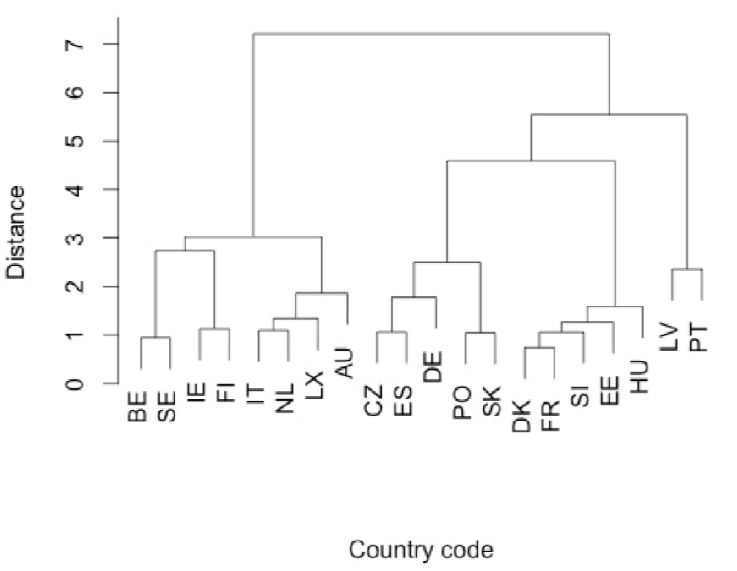

Fig. 4. Cluster analysis of business statistics by Ward's method (Source: author's calculations)

Instead there is a mixture (see Figs 3 and 4):

1. 'Cluster 1'consists of Belgium, the Netherlands, Luxembourg, and Austria, but also Sweden and Italy.

2. 'Cluster 2' consists of Denmark and France together with Slovenia, Estonia, and Hungary. 
3. The Ireland in pair with Finland adding itself to one of the two previous clusters depending on the method used.

4. 'Cluster 3' consists of Spain together with the Czech Republic, Poland, and Slovakia;

5. Germany adding itself to 'Cluster 1' or 'Cluster 3' depending on the method used.

6. Latvia in a pair with Portugal is having the biggest distance to all other clusters by both methods, forming a case of an outlier.

The distance between Latvia and Portugal, and other EU countries can be explained by their unusually high birth but low survival rates. The birth rate is above $12 \%$ for Portugal and above $16 \%$ for Latvia; at the same time these are the only two countries in the sample with survival rates below $50 \%$. At the other end with the lowest birth rates but the highest survival rates are Belgium and Sweden, followed by the Netherlands and Austria (see Fig. 5). There is moderate negative correlation between these two variables $(-0.65)$.

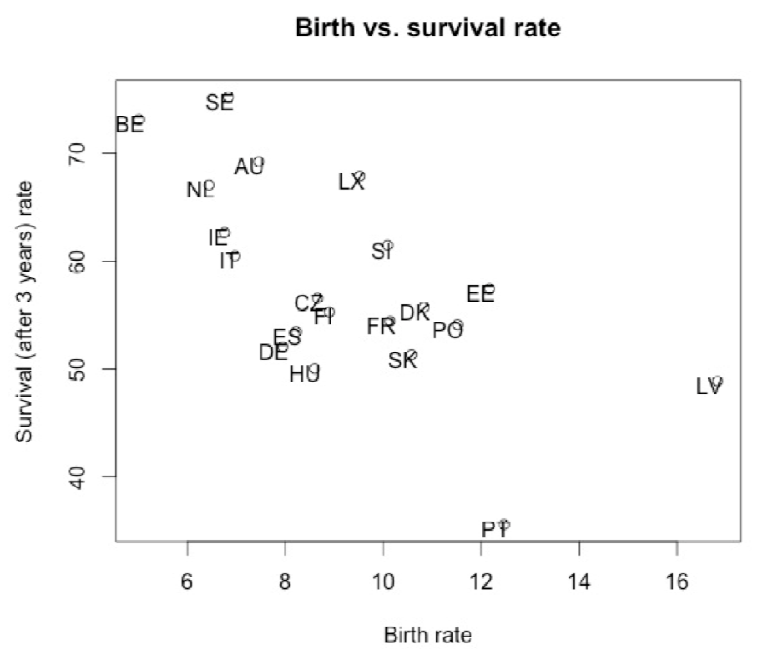

Fig. 5. Birth vs. survival rates (Source: author's calculations)

Portugal and Latvia are also with the highest share of employment in births. The lowest employment in births is in Ireland and Finland (see Fig. 6).

There is no correlation between Starting a Business indicator and birth or survival rate. At the same time the Starting a Business indicator affects the cluster creation, because some Central European countries like Austria, Germany, and Luxembourg are among the worst performers in the EU together with Spain, Poland, and the Czech Republic (see Table 1). This is where some of geographical linkages break in the flexicurity analysis when business start-up indicators are incorporated.

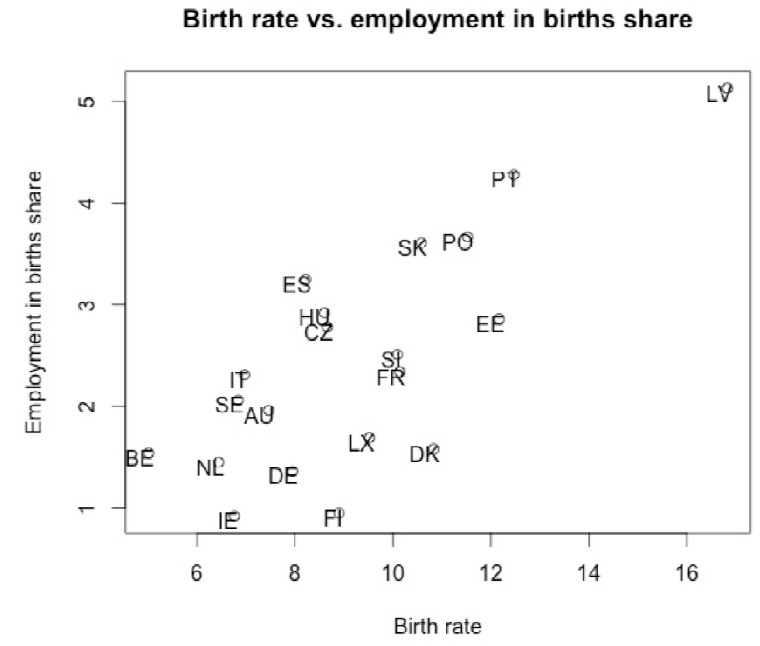

Fig. 6. Birth rate vs. employment in births share (Source: author's calculations)

Table 1. Starting a Business indicator, distance to frontier in \% of the best performer (Source: World Bank Group, Doing Business index)

\begin{tabular}{cccc}
\hline $\begin{array}{c}\text { Country } \\
\text { Code }\end{array}$ & $\begin{array}{c}\text { Starting a } \\
\text { Business }\end{array}$ & $\begin{array}{c}\text { Country } \\
\text { Code }\end{array}$ & $\begin{array}{c}\text { Starting a } \\
\text { Business }\end{array}$ \\
\hline PT & 94.55 & EE & 90.86 \\
SI & 94.42 & IT & 88.37 \\
BE & 94.35 & NL & 86.92 \\
HU & 93.15 & SK & 86.85 \\
FI & 93.08 & LX & 86.81 \\
DK & 92.77 & CZ & 83.01 \\
FR & 92.50 & PO & 81.85 \\
IE & 92.40 & DE & 81.62 \\
SE & 92.22 & AU & 79.65 \\
LV & 91.50 & ES & 78.19 \\
\hline
\end{tabular}

Findings of cluster formation when both data sets are used then lead to somewhere more diverse results that in traditional flexicurity analysis and a higher mix between Central, Southern, and Eastern European countries (see Figs 7 and 8). Because of the preference to results of Ward's method over regular Average Linkage method, four final clusters can be defined:

1. Scandinavian cluster (Denmark, Finland, and Sweden).

2. Quasi-Central European cluster (Belgium, Ireland, Germany, Austria, and the Netherlands together with Spain and Italy).

3. Quasi-Eastern European cluster (Czech Republic, Poland, Slovakia, Estonia, Hungary, and Slovenia together with France and Luxembourg).

4. Outlier pair of Latvia and Portugal. 


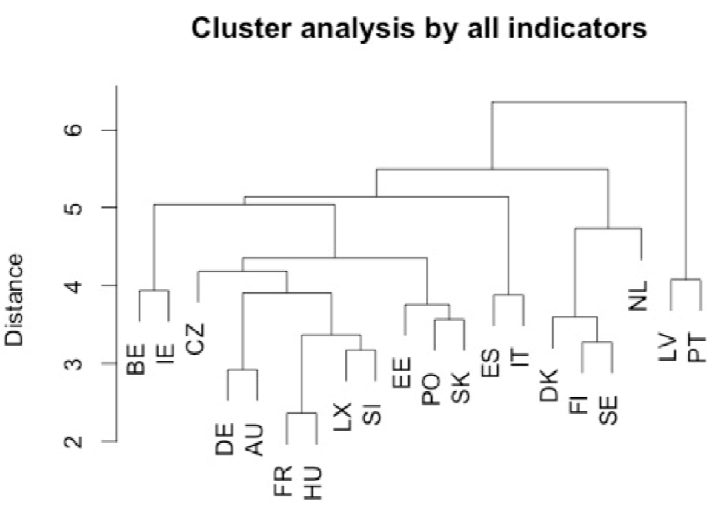

Country code

Fig. 7. Cluster analysis of combined data by Average Linkage method (Source: author's calculations)

Cluster analysis by all indicators (Ward)

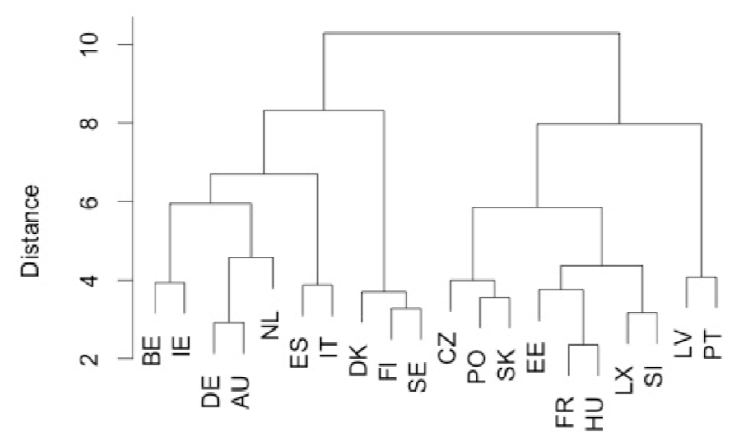

Country code

Fig. 8. Cluster analysis of combined data by War's method (Source: author's calculations)

Scandinavian cluster is located closer to quasi-Central European cluster, while the pair of Latvia and Portugal to quasi-Eastern European cluster. This shows that geographical dimension is still strong and flexicurity together with supportive entrepreneurial policy is better developed in Central than Eastern Europe. As for example, there are the highest part-time employment rates in the Netherlands, Germany, Austria, Sweden, Denmark, Belgium, and Ireland (from 23.5 to $49 \%$ ). In most of these countries there is moderate EPL and high expenditures for ALMP. The highest poverty rates (above 17\%) are in Spain, Italy, Latvia, Poland, Estonia, and Portugal, where the GINI index is also the highest (above 30). While Eastern European countries are having higher business birth rates and employment in births, survival rates are the highest for Central Europe. Very importantly, only in the Scandinavian countries - Denmark, Sweden, and
Finland - is the LLL rate above $20 \%$, namely $31.6 \%, 26.7 \%$, and $24.5 \%$. It is followed by the Netherlands (16.5\%) and Austria (14.1\%).

The Scandinavian cluster is the real benchmark for Europe, where the labour market flexicurity is implemented together with support for entrepreneurial activity. It is characterised by the highest LLL, part-time employment rate, highest expenditure on ALMP, but lowest long-term unemployment, poverty rate and GINI index. In business statistics Scandinavian countries are not characterised by high birth rate and employment in births, but by high Starting a Business indicators (above 90 out of 100) and survival rates $-75.2 \%$ for Sweden, 55.7\% for Denmark, and 55.3\% for Finland. However, improvements in business activity could be promoted, when compared to other European countries.

\section{Conclusions}

Focus on and financial assistance for selfemployment and start-up incentives increased in the EU during the last decades or so, especially with attention to unemployed people starting their entrepreneurial activity through ALMP programmes. However, there is no clear causality between unemployment variation and entrepreneurship; rather bidirectional causality has been found especially in flexible labour markets (Faria et al. 2010). At the same time the effectiveness of startup incentives is estimated to be positive. Furthermore, positive effect is seen on every start-up, whatever the starting status has been. This explains why the "refugee" effect is found to be relatively small (Thurik et al. 2008) but instead the "Schumpeter effect" often holds true. Therefore, the policy should be focused on encouraging entrepreneurship for the general population, which would lead to a decrease in unemployment through individuals becoming employed on their own or by other startups. At the same time, to maximise the effect of new businesses, in long-term start-up incentives should focus on high-growth company creation. In the short-term, in periods of economic and job crisis, start-up incentives are needed to reduce unemployment fast; this is when the "refugee" effect is found to be working the most.

As said by Roman et al. (2013): "It is also since start-up programmes are the objectives of ALMP, when start-ups became part of employment policy instead of entrepreneurship policy". ALMP instruments are already incorporated in the flexicurity analysis, including spending on start-up incentives. But the flexicurity concept so far did not in- 
clude data on start-up activity or programme efficiency. Based on variables used in the analysis by Baumgartner and Caliendo (2008), Millan et al. (2010) and Roman et al. (2013) to estimate the effectiveness of start-up incentives, this paper suggests including the following indicators in the flexicurity concept: enterprise birth rate, employment in newly-born enterprises, and survival rate (over 3 years) by Eurostat, as well as Starting a Business indicator from the Doing Business index by the World Bank Group, which would capture the legislative part of the entrepreneurial policy similar to the EPL, which characterises employment policy.

By using the Agglomerative Hierarchical Clustering, it is found that changes occur when incorporating the new business start-up indicators in the traditional flexicurity analysis. At the lower level, mostly the Central and Eastern European countries are grouped differently and do not have that strong geographical perspective as earlier. Therefore, in the broader approach of flexicurity, the number of Eastern European countries is able to actually "catch up" with Central European countries.

Three clusters are found in the final flexicurity analysis, where business statistics is incorporated: (a) quasi-Central European cluster, which consists of Belgium, Ireland, Germany, Austria, and the Netherlands together with Spain and Italy; (b) quasi-Eastern European cluster, which consists of Czech Republic, Poland, Slovakia, Estonia, Hungary, and Slovenia together with France and Luxembourg; and (c) Scandinavian cluster (Denmark, Finland, and Sweden). Latvia and Portugal have become an outlying pair in this analysis, because of an unusually high entrepreneurial birth rates and employment in births; but they are the only two countries in the sample that have survival rates below $50 \%$. The Scandinavian cluster is located closer to the quasi-Central European cluster, while the pair of Latvia and Portugal to quasiEastern European cluster.

The Scandinavian cluster is found to be the real benchmark for Europe, where the labour market flexicurity is implemented together with support for entrepreneurial activity. It is characterised by the highest LLL, part-time employment rate, highest expenditure on ALMP, but lowest longterm unemployment, poverty rate and GINI index. In business statistics, Scandinavian countries are not characterised by high birth rate and employment in births, but Starting a Business indicators are above 90 (out of 100) and survival rates are above $55 \%$.
To conclude, the outcome of country performance and cluster analysis changes substantially, when business start-up statistics is incorporated in the flexicurity analysis. However, further analysis is needed also on other business related indicators to find the best cover of the entrepreneurship as an alternative form of employment.

The main limitation of the clustering in this research is the omitted countries; they would give additional information and improve the formation of groups. As for example, Latvia and Portugal is now forming an outlying pair, but results could change if Lithuania and Greece was in the sample.

\section{References}

Andersen, T. M. 2012. A flexicurity labour market in the Great Recession: the case of Denmark, De Economist 160: 117-140. http://dx.doi.org/10.1007/s10645-011-9181-6

Audretsch, D. B.; Carree, M. A.; Van Stel, A. J.; Thurik, A. R. 2005. Does self - employment reduce unemployment? [online], [cited 10 December 2015.] Available from Internet: http://papers.ssrn.com/soL3/papers.cfm?abstract_i $\mathrm{d}=775830$

Baumgartner, H.; Caliendo, M. 2008. Turning unemployment into self-employment: effectiveness of two start-up programmes, Oxford Bulletin of Economics and Statistics 70(3): 347-373.

http://dx.doi.org/10.1111/j.1468-0084.2008.00505.x

Boeri, T.; Conde-Ruiz, J. I.; Galasso, V. 2012. The political economy of flexicurity, Journal of the European Economic Association 10(4): 684-715.

http://dx.doi.org/10.1111/j.1542-4774.2012.01065.x

Caliendo, M.; Kunn, S. 2011. Start-up subsidies for the unemployed: long-term evidence and effect heterogeneity, Journal of Public Economics 95(3-4): 311-331. http://dx.doi.org/10.1016/j.jpubeco.2010.11.003

Cichocki, S. 2012. Self-employment and the business cycle: evidence from Poland, Post-Communist Economies 24(2): 219-239.

http://dx.doi.org/10.1080/14631377.2012.675157

Card, D.; Kluve, J.; Weber, A. 2010. Active labor market policy evaluations: a meta - analysis [online], [cited 07 January 2016.] Available from Internet: http://www.nber.org/papers/w16173

Congregado, E.; Millan, J. M.; Roman, C. 2010a. From own - account worker to job creator. Social Science Research Net (SSRN). Available from Internet: http://ssrn.com/abstract $=1557330$

Congregado, E.; Golpe, A. A.; Carmona, M. 2010b. Is it a good policy to promote self - employment for job creation? Evidence from Spain, Journal of Policy Modeling 32: 828-842. http://dx.doi.org/10.1016/j.jpolmod.2010.09.001 
Dal Bianco, S.; Bruno, R. L.; Signorelli, M. 2015. The joint impact of labour policies and the "Great Recession" on unemployment in Europe, Economic Systems 39: 3-26.

http://dx.doi.org/10.1016/j.ecosys.2014.06.002

Eamets, R.; Humal, J.; Beblavy, M.; Maselli, I.; Bheemaiah, K.; Smith, M.; Finn, M.; Leschke, J. 2015. Mapping flexibility and security performance in the face of the crisis. Brighton: University of Brighton.

European Commission (EC). 2010. Towards a set of composite indicators on flexicurity: a comprehensive approach [online], [cited 05 January 2016.]. Available from Internet: http://publications.jrc. ec.europa.eu/repository/handle/JRC58069

European Commission (EC). 2012. Evaluation of flexicurity 2007-2010: final report [online], [cited 19.12.2015.]. Available from Internet: http://ec.europa.eu/social/BlobServlet?docId=1001 8\&langId $=$ en

European Council. 2005. Employment policy guidelines (2005-2008). Council Decision 2005/600/EC of 12 July 2005 on guidelines for the employment policies of the Member States.

European Foundation for the Improvement of Living and Working Conditions (Eurofound). 2007. Approaches to flexicurity: EU models [online], [cited 01 December 2015.]. Available from Internet: https://www.eurofound.europa.eu/sites/default/file s/ef_files/pubdocs/2007/84/en/1/ef0784en.pdf

Faria, J. R.; Cuestas, J. C.; Mourelle, E. 2010. Entrepreneurship and unemployment: a nonlinear bidirectional causality?, Economic Modelling 27: 12821291. http://dx.doi.org/10.1016/j.econmod.2010.01.022

Fritsch, M.; Kritikos, A.; Pijnenburg, K. 2013. Business cycles, unemployment and entrepreneurial entry: evidence from Germany, Discussion paper 7852. Institute for the Study of Labor (IZA)

Halicioglu, F.; Yolac S. 2015. Testing the impact of unemployment on self - employment: evidence from OECD countries, Procedia - Social and Behavioral Sciences 195: 10-17. http://dx.doi.org/10.1016/j.sbspro.2015.06.161

Hujer, R.; Rodrigues, P. J. M.; Wolf, K. 2009. Estimating the macroeconomic effects of active labour market policies using spatial econometric methods, International Journal of Manpower 30(7): 648-671.
Madsen, P. K. 2005. How can it possibly fly? The paradox of a dynamic labour market in a Scandinavian welfare state, Research paper 2005: 2. Centre for Labour Market Research (CARMA)

Maselli, I. 2010. Beyond flexibility and security. A composite indicator of flexicurity, Working Document 329. Centre for European Policy Studies (CEPS).

Millan, J. M.; Congregado, E.; Roman, C. 2010. Determinants of self - employment survival in Europe, Small Business Economics 38: 231-258. http://dx.doi.org/10.1007/s11187-010-9260-0

Muffels, R. J. A.; Wilthagen, A. C. J. M. 2013. Flexicurity: a new paradigm for the analysis of labor markets and policies challenging the trade - off between flexibility and security, Sociology Compass 7(2): 111-122. http://dx.doi.org/10.1111/soc4.12014

Origo, F.; Pagani, L. 2009. Flexicurity and job satisfaction in Europe: the importance of perceived and actual job stability for well-being at work, Labour Economics 16: 547-555. http://dx.doi.org/10.1016/j.labeco.2009.02.003

Roman, C.; Congregado, E.; Millan, J. M. 2013. Startup incentives: entrepreneurship policy or active labour market programme? Journal of Business Venturing 28(1): 151-175. http://dx.doi.org/10.1016/j.jbusvent.2012.01.004

Tangian, A. 2007. European flexicurity: concepts, methodology and policies, Transfer 13(4): 551-573. http://dx.doi.org/10.1177/102425890701300404

Thurik, A. R.; Carree, M. A.; Van Stel, A.; Audretsch, D. B. 2008. Does self-employment reduce unemployment?, Journal of Business Venturing 23: 673-686. http://dx.doi.org/10.1016/j.jbusvent.2008.01.007

Vaivade A.; Brekis E. 2015. Estimation of flexicurity level in EU/EEA countries using the Fuzzy logic approach, in $9^{\text {th }}$ International Days of Statistics and Economics, 10-12 September 2015, Prague, Czech Republic.

Van Oorschoot, W.; Engelfriet, R. 2000. Work Work Work. Labour Market Participation Policies in the Netherlands 1970-2000 [online], [cited 18 December 2015.]. Available from Internet: https://perswww.kuleuven.be/ u0079125/wvo/Arti kelenOnline/work work work.pdf 